\title{
Effect of Organic Nutrient Sources on Biological Properties of Soil in Potato and Turmeric Cropping System
}

\author{
Anjali Verma*, Uday Sharma, D. Tripathi and Meera Devi
}

Department of Soil Science and Water Management, Dr Y S Parmar University of Horticulture and Forestry, Nauni, Himachal Pradesh-173 230, India

*Corresponding author

\section{A B S T R A C T}

The field experiment was conducted during 2016-17 and 2017-18 to study the effect of organic nutrient sources on soil biological properties of potato and

Keywords

FYM, Vermicompost, Poultry Manure,

Organic manures, Soil enzymes

Article Info

Accepted:

10 July 2019

Available Online:

10 August 2019 turmeric. The field experiments were laid out in randomized block design with four replications and eight treatments. The eight treatments were $\mathrm{T}_{1}(100 \% \mathrm{RD} \mathrm{N}$ through VC \& PM on 50:50 N-equivalence basis), $\mathrm{T}_{2}$ (90\% RD N through VC \& $\mathrm{PM}$ on 50:50 N equivalence basis), $\mathrm{T}_{3}$ (80\% RD N through VC \& PM on 50:50 Nequivalence basis), $\mathrm{T}_{4}(70 \% \mathrm{RD} \mathrm{N}$ through $\mathrm{VC} \& \mathrm{PM}$ on 50:50 N-equivalence basis), $\mathrm{T}_{5}\left(60 \% \mathrm{RD} \mathrm{N}\right.$ through $\mathrm{VC} \& \mathrm{PM}$ on 50:50 $\mathrm{N}$ equivalence basis), $\mathrm{T}_{6}$ (50\% RD N through VC \& PM on 50:50 N-equivalence basis), $\mathrm{T}_{7}$ (40\% RD N through VC \& PM on 50:50 N-equivalence basis) and $\mathrm{T}_{8}$ (Control only FYM). Organic nutrient sources significantly influenced microbial properties of potato and turmeric. The microbial properties were higher in $\mathrm{T}_{1}(100 \% \mathrm{RD} \mathrm{N}$ through VC \& $\mathrm{PM}$ on 50:50 N-equivalence basis) treatment and lowest in control. The application of $100 \%$ RD N showed positive impact on microbial properties of soil and also enhanced fertility status of soil, which ultimately reflects a healthy soil.

\section{Introduction}

Soil harbors dynamic population of microorganisms which play major role in decomposition of organic matter and transformation of plant nutrients. The availability of organically bound nitrogen through transformation in soil to the plant mainly depends on the population of microorganisms, which is influenced by the application of organic manure. The microbial biomass, which is the total mass of bacteria, fungi, actinomycetes present in soil, serves as a temporary sink for nutrients including nitrogen and can be considered as an index of soil fertility. The factors like cropping system, manure application etc., affects the soil microbial growth, activity and diversity. Microbial biomass carbon and enzyme activity increases with continuous application of organic manure (Zhao et al., 2016). Enzymes are important soil components involved in dynamics of soil nutrient transformations and enzyme activity is considered to be a major 
contributor of overall soil microbial activity. Microorganisms and their mediated processes can give an integrated measure of soil health. It also plays an important role in organic matter decomposition and in the dynamics of nutrient transformations in the soil. Addition of organic manures significantly increases the urease, alkaline phosphatase and dehydrogenase activity in the soil as compared to chemical fertilizers and also very little attention has been paid on potato- turmeric cropping system. Hence, experiment was planned to study the effects of organic manures on the soil microbial properties.

\section{Materials and Methods}

The experiment was conducted during two crop year (2016-2018) at the experimental farm of Department of Soil Science and Water Management, Dr. YS Parmar University of Horticulture and Forestry, Nauni, Solan (HP). It is located at $30^{\circ} 51^{\prime} \mathrm{N}$ latitude and $76^{\circ} 11^{\prime} \mathrm{E}$ longitude at an elevation of $1175 \mathrm{~m}$ above mean sea level and has an average slope of 7-8 per cent. The soil (Eutrochrept) was gravelly sandy loam in texture and neutral in reaction.

The experiment was laid out with eight treatments combinations replicated four times in RBD factorial design. The treatments were viz. $\mathrm{T}_{1}(100 \% \mathrm{RD} \mathrm{N}$ through $\mathrm{VC} \& \mathrm{PM}$ on 50:50 N-equivalence basis), $\mathrm{T}_{2}$ (90\% RD N through VC \& PM on 50:50 N-equivalence basis), $\mathrm{T}_{3}$ (80\% RD N through VC \& PM on 50:50 N-equivalence basis), $\mathrm{T}_{4}(70 \% \mathrm{RD} \mathrm{N}$ through VC \& PM on 50:50 N-equivalence basis), $\mathrm{T}_{5}$ (60\% RD $\mathrm{N}$ through VC \& PM on 50:50 N-equivalence basis), $\mathrm{T}_{6}(50 \% \mathrm{RD} \mathrm{N}$ through $\mathrm{VC} \& \mathrm{PM}$ on 50:50 N-equivalence basis), $\mathrm{T}_{7}$ (40\% RD N through VC \& PM on 50:50 N-equivalence basis) and $\mathrm{T}_{8}$ (Control only FYM). The sources of nutrients were farm yard manure (FYM), vermicompost (VC) and poultry manure (PM). The experiment plot size was $9 \mathrm{~m}^{2}$

\section{Soil sampling}

Composite soil samples from $0-15 \mathrm{~cm}$ depth were collected before the onset of the experiment and after final harvesting in potato and turmeric. Collected soil samples were air dried in shade and ground with the help of wooden pestle and mortar. These ground samples were then passed through $2 \mathrm{~mm}$ sieve and stored in plastic boxes and analyzed as per the methods discussed against each parameter. The soil samples were analyzed for different microbial activity by adopting standard procedures as described below:

\section{Microbial biomass carbon Fumigation-Extraction Method)}

(Soil

Microbial biomass carbon was determined by soil fumigation- extraction method as detailed by Vance et al., (1987). In this method, $10 \mathrm{~g}$ of soil was fumigated with $20 \mathrm{ml}$ of $\mathrm{CHCl}_{3}$ in vacuum desiccators for 24 hours in dark, and other $10 \mathrm{~g}$ of same soil sample was refrigerated, then both the samples (fumigated and unfumigated) were extracted with $0.5 \mathrm{M}$ $\mathrm{K}_{2} \mathrm{SO}_{4}$ for half an hour and then the extract was treated with $\mathrm{H}_{2} \mathrm{SO}_{4}$ and orthophosphoric acid and heated on hot plate at $120^{\circ} \mathrm{C}$ for 30 minutes.

The resultant material was diluted to $250 \mathrm{ml}$ with distilled water and 2-3 drops of ferroin indicator were added and titrated against 0.005 N FAS (Ferrous Ammonium Sulphate) and

\section{Dehydrogenase activity}

Soil dehydrogenase activity was determined by estimating the rate of production of triphenyl formazan (TPF) from triphenyl tetrazolium (Casida et al., 1964). Distilled water and $1 \mathrm{ml}$ TTC (3\%) were added to soil sample $(3 \mathrm{~g})$ and incubated at $37^{\circ} \mathrm{C}$ for 24 hours. Soil solution was washed with methanol $(50 \mathrm{ml})$ to remove reddish colour. 
The red colour intensity was measured at 485 nm.

\section{Alkaline phosphatase activity}

Alkaline phosphatase activity was assessed by method described by Tabatabai and Bremner, 1969. The phosphatase enzyme activity was estimated by taking $1 \mathrm{~g}$ of soil with $0.2 \mathrm{ml}$ toluene, $4 \mathrm{ml}$ of modified universal buffer (MUB, $\mathrm{pH} 11$ ) and $1 \mathrm{ml}$ of p-nitrophenyl phosphate (PNP). After incubation for 1 hour at $37 \mathrm{oC}$, the enzyme reaction was stopped by adding $4 \mathrm{ml}$ of $0.5 \mathrm{M} \mathrm{NaOH}$ and $1 \mathrm{ml}$ of 0.5 $\mathrm{M} \mathrm{CaCl2}$. Soil suspension was filtered and absorbance was measured at $420 \mathrm{~nm}$.

\section{Urease activity}

$10 \mathrm{~g}$ of dry and sieved soil was incubated for 15 min with $15 \mathrm{ml}$ of toluene. $10 \mathrm{ml}$ of urea solution and $20 \mathrm{ml}$ of citrate buffer were added, mixed and incubated for 3 hours at $37^{\circ}$ $\mathrm{C}$, then diluted to $100 \mathrm{ml}$ with water, mixed and filtered. $1 \mathrm{ml}$ of filtrate was pipetted out, added $9 \mathrm{ml}$ of water, $4 \mathrm{ml}$ phenate solution and $3 \mathrm{ml}$ of sodium hypochlorite solution. It was mixed and allowed to stand for 20 minutes until the maximum colour was obtained. It was then diluted to $50 \mathrm{ml}$ with water, mixed well, and the transmittance/absorbance read at $630 \mathrm{~nm}$ against the blank. The standard curve was prepared from ammonium sulphate solution $\left(10 \mu \mathrm{g} \mathrm{N} \mathrm{ml}^{-1}\right)$. Results were expressed as $\mu \mathrm{g}$ $\mathrm{NH}_{4}{ }^{+}$per $\mathrm{g}$ soil per hr to get Urease number. Urease number was multiplied by 0.32 to obtain urease units (Kandeler and Gerber, 1988).

Total microbial count (bacteria, fungi and actinomycetes) in soil

The serial dilution and plating techniques suggested by Subba Rao (1999) were employed for isolation and identification of viable bacteria, actinomycetes and fungi count. Media were prepared for desired micro flora. The autoclaved and cooled $\left(45^{\circ} \mathrm{C}\right)$ medium was poured into sterile plates and allowed to solidify. One gram of sieved $(<2$ $\mathrm{mm}$ ) soil was added to $9 \mathrm{ml}$ sterile water blank and shaken for 15-20 minutes. Serial dilutions of $10^{-2}, 10^{-3}, 10^{-4}, 10^{5}, 10^{-6}$ and $10^{-7}$ were prepared and $0.1 \mathrm{ml}$ of aliquots of various dilutions were added, over cooled and solidified medium in petriplates, using the pour plate method. The plates were rotated for uniform distribution of bacterial cells and fungal spores in the aliquot under the media and allowed to solidify. After the media was solidified, the plates were inverted and incubated at $28^{0} \mathrm{C}$ for 3-4 days. The appearance of colonies on the surface of the medium in the plates was observed. Population count of bacteria, fungi and actinomycetes was noted using dilution plate technique by employing nutrient agar (NA), potato dextrose agar medium (PDA) and Kenknight's media, respectively. The population was expressed as colony forming units (cfu/g soil).

\section{Results and Discussion}

\section{Microbial biomass carbon}

Highest microbial biomass carbon was recorded under treatment $\mathrm{T}_{1}$ (228.19 and $257.19 \mu \mathrm{g} \mathrm{g} \mathrm{soil}{ }^{-1}$ ) in potato and turmeric, respectively, which were statistically at par with $\mathrm{T}_{2}\left(223.22\right.$ and $\left.245.87 \mu \mathrm{g} \mathrm{g} \mathrm{soil}{ }^{-1}\right)$ for respective crops whereas, the lowest microbial biomass-C was recorded under control $\left(\mathrm{T}_{8}\right)$ with values of 206.41 and $209.18 \mu \mathrm{g} \mathrm{g} \mathrm{soil}^{-1}$ ) for potato and turmeric crops, respectively. Application of balanced amount of nutrients and manure improve the microbial biomass carbon of soil. Increase in microbial biomass carbon with addition of fertilizers or organic manure may be attributed to better crop growth, increased root biomass and root 
exudates (Shahid et al., 2013 and Biswas et al., 2018) which stimulated the proliferation of microorganism (Bhattacharya et al., 2008). Furthermore, the supply of additional mineralizable and readily hydrolysable $\mathrm{C}$ due to organic manure application results in higher microbial activity and higher microbial biomass carbon (Ingle et al., 2014).

\section{Dehydrogenase activity}

Application of different organic sources exerted a significant influence on the dehydrogenase enzyme activity. The dehydrogenase activity was found maximum under $\mathrm{T}_{1}$ i.e. $100 \% \mathrm{RD} \mathrm{N}$ through $\mathrm{VC} \& \mathrm{PM}$ on 50:50 N-equivalence basis $(64.30 \mu \mathrm{g}$ TPF g soil ${ }^{-1} 24 \mathrm{hr}^{-1}$ ) being statistically at par with $\mathrm{T}_{2}$ (61.47 $\mu \mathrm{g}$ TPF g soil ${ }^{-1} 24 \mathrm{hr}^{-1}$ ) and the lowest under control i.e. $52.30 \mu \mathrm{g}$ TPF g soil ${ }^{-1} 24 \mathrm{hr}^{-1}$. Optimum and balanced application of nutrients led to significant increase in dehydrogenase activity. Dehydrogenase activity was increased in $\mathrm{T}_{1}$ i.e. $100 \% \mathrm{RD} \mathrm{N}$ through VC \& PM on 50:50 N-equivalence basis which may be due to a strong relationship between soil organic matter content which increases microbial biomass carbon and subsequently higher enzyme activities (Mandal et al., 2007). The results are in accordance with the results of Liu et al., (2010). It can be explained based on the fact that dehydrogenase activity is influenced rather by the quality than by quantity of organic manure incorporated into the soil.

The enzyme activities in the soil are closely related to organic matter content and greater activities of dehydrogenase, in this treatment may also be due to enhanced microbial activity. Application of balanced amount of nutrients and manure improve the microbial biomass carbon status of soil which corresponds to higher enzyme activity Mandal et al., 2007. Increase in dehydrogenase activity has also been observed by Liu et al.,
2010 and Moharana et al., 2014, with the addition of organic manures. These results are also in line with the findings of Kashyap and Khokhar (2017).

\section{Alkaline phosphatase activity}

The alkaline phosphatase activity in the soil did not vary significantly with the application of different organic sources. The highest values of phosphatase were noticed under application of $100 \%$ RD N through VC \& PM on 50:50 N-equivalence basis and highest phosphatase content was recorded under $\mathrm{T}_{1}$ (521.67 and 577.89 $\mu \mathrm{g}$ PNP g soil ${ }^{-1} \mathrm{hr}^{-1}$ and lowest under control (471.71 and $469.70 \mu \mathrm{g}$ PNP g soil ${ }^{-1} \mathrm{hr}^{-1}$.

The results are in line with findings of Mohammadi et al., (2011) and Akca et al., (2015), who ascribed higher activity to the better microbial carbon pool in the organic treatments at higher levels.

\section{Urease activity}

Application of different organic sources exerted a non-significant influence on the urease enzyme (Table 4.50) in soils after the harvest of both potato and turmeric crops. The highest values of urease were noticed under application of (100\% RD N through VC \& PM on 50:50 N-equivalence basis) i.e. $\mathrm{T}_{1}(65.24$ and $\left.72.21 \mu \mathrm{g}\left(\mathrm{NH}_{4}\right)^{+}(\mathrm{g} \text { soil })^{-1} \mathrm{hr}^{-1}\right)$ and lowest under control with values of 59.02 and 58.77 $\mu \mathrm{g}\left(\mathrm{NH}_{4}\right)^{+}(\mathrm{g} \text { soil })^{-1} \mathrm{hr}^{-1}$, for the two respective crops. Raju et al., (2013) and Lakshmi et al., (2014) also observed an increase in urease activity with the increasing inputs of organics in soil.

\section{Bacterial count}

The bacterial population was significantly enhanced by the application of organic nutrient sources. 
Table.1 Effect of organic nutrient sources on microbial biomass carbon and dehydrogenase activity of soil

\begin{tabular}{|c|c|c|c|c|}
\hline \multirow[t]{2}{*}{ Treatment } & \multicolumn{2}{|c|}{ Microbial biomass carbon $\left(\mu \mathrm{g} \mathrm{g} \mathrm{soil}^{-1}\right)$} & \multicolumn{2}{|c|}{ Dehydrogenase $\left(\mu \mathrm{g}\right.$ TPF g soil $\left.{ }^{-1} 24 \mathrm{hr}^{-1}\right)$} \\
\hline & Potato & Turmeric & Potato & Turmeric \\
\hline $\mathbf{T}_{1}$ & 228.19 & 257.19 & 55.96 & 64.30 \\
\hline $\mathbf{T}_{2}$ & 223.22 & 245.87 & 54.75 & 61.47 \\
\hline $\mathbf{T}_{3}$ & 216.92 & 231.92 & 53.22 & 57.98 \\
\hline $\mathbf{T}_{4}$ & 216.79 & 219.25 & 53.39 & 54.81 \\
\hline $\mathbf{T}_{5}$ & 215.11 & 217.21 & 52.78 & 54.30 \\
\hline $\mathbf{T}_{6}$ & 212.01 & 216.64 & 52.23 & 54.16 \\
\hline $\mathbf{T}_{7}$ & 210.94 & 216.43 & 51.74 & 54.11 \\
\hline $\mathbf{T}_{8}$ & 206.41 & 209.18 & 50.63 & 52.30 \\
\hline $\mathrm{CD}_{(0.05)}$ & 9.47 & 17.24 & 2.33 & 4.31 \\
\hline
\end{tabular}

Table.2 Effect of organic nutrient sources on alkaline phosphatase and urease activity of soil

\begin{tabular}{|c|c|c|c|c|}
\hline \multirow[t]{2}{*}{ Treatment } & \multicolumn{2}{|c|}{$\begin{array}{c}\text { Alkaline phosphatase }(\mu \mathrm{g} \text { PNP g } \\
\left.\text { soil }^{-1} \mathbf{h r}^{-1}\right)\end{array}$} & \multicolumn{2}{|c|}{ Urease $\left(\mu \mathrm{g}\left(\mathrm{NH}_{4}\right)^{+}\left(\mathrm{g} \mathrm{soil}^{-1} \mathrm{hr}^{-1}\right)\right.$} \\
\hline & Potato & Turmeric & Potato & Turmeric \\
\hline $\mathbf{T}_{1}$ & 521.67 & 577.89 & 65.24 & 72.21 \\
\hline $\mathbf{T}_{2}$ & 510.13 & 552.21 & 63.83 & 69.06 \\
\hline $\mathbf{T}_{3}$ & 495.52 & 521.20 & 62.03 & 65.11 \\
\hline $\mathbf{T}_{4}$ & 497.23 & 492.19 & 62.23 & 61.62 \\
\hline $\mathbf{T}_{\mathbf{5}}$ & 491.42 & 487.53 & 61.51 & 61.05 \\
\hline $\mathbf{T}_{6}$ & 486.60 & 486.28 & 60.88 & 60.89 \\
\hline $\mathbf{T}_{7}$ & 482.06 & 485.73 & 60.31 & 60.84 \\
\hline $\mathbf{T}_{8}$ & 471.71 & 469.70 & 59.02 & 58.77 \\
\hline $\mathrm{CD}_{(0.05)}$ & NS & NS & NS & NS \\
\hline
\end{tabular}

Table.3 Effect of organic nutrient sources on viable bacterial, fungal and Actinomycetes count of soil

\begin{tabular}{|c|c|c|c|c|c|c|}
\hline \multirow[t]{2}{*}{ Treatment } & \multicolumn{2}{|c|}{$\begin{array}{l}\text { Bacterial count } \\
\left(\times 10^{5} \mathrm{cfu} \mathrm{g}^{-1}\right)\end{array}$} & \multicolumn{2}{|c|}{$\begin{array}{l}\text { Fungal count } \\
\left(\times 10^{3} \mathrm{cfu} \mathrm{g}^{-1}\right)\end{array}$} & \multicolumn{2}{|c|}{$\begin{array}{l}\text { Actinomycetes count } \\
\qquad\left(\times 10^{3} \mathrm{cfu} \mathrm{g}^{-1}\right)\end{array}$} \\
\hline & Potato & Turmeric & Potato & Turmeric & Potato & Turmeric \\
\hline $\mathbf{T}_{1}$ & 18.7 & 19.8 & 3.65 & 3.58 & 2.71 & 2.85 \\
\hline $\mathbf{T}_{2}$ & 18.7 & 19.6 & 3.45 & 3.53 & 2.61 & 2.70 \\
\hline $\mathbf{T}_{3}$ & 18.6 & 19.3 & 3.21 & 3.35 & 2.46 & 2.65 \\
\hline $\mathbf{T}_{4}$ & 18.5 & 19.3 & 2.85 & 3.25 & 2.38 & 2.60 \\
\hline $\mathbf{T}_{5}$ & 18.4 & 19.2 & 2.79 & 2.93 & 2.26 & 2.54 \\
\hline$T_{6}$ & 18.2 & 18.9 & 2.61 & 2.93 & 2.26 & 2.48 \\
\hline $\mathbf{T}_{7}$ & 17.3 & 18.5 & 2.54 & 2.86 & 2.25 & 2.41 \\
\hline $\mathbf{T}_{8}$ & 16.9 & 17.9 & 2.40 & 2.68 & 2.11 & 2.18 \\
\hline $\mathrm{CD}_{(0.05)}$ & 0.5 & 1.0 & 0.23 & 0.23 & 0.25 & 0.16 \\
\hline
\end{tabular}


The data pertaining to soil bacteria revealed that soil receiving $100 \%$ RD N through VC \& PM on 50:50 N-equivalence basis $\left(T_{1}\right)$ in potato, recorded maximum bacterial count $\left(18.7 \times 10^{5} \mathrm{cfu} \mathrm{g}^{-1}\right)$ which was statistically at par with $\mathrm{T}_{2}\left(18.7 \times 10^{5} \mathrm{cfu} \mathrm{g}^{-1}\right), \mathrm{T}_{3}\left(18.6 \times 10^{5}\right.$ cfu g $\left.{ }^{-1}\right), \mathrm{T}_{4}\left(18.5 \times 10^{5} \mathrm{cfu} \mathrm{g}^{-1}\right), \mathrm{T}_{5}\left(18.4 \times 10^{5}\right.$ cfu $\left.\mathrm{g}^{-1}\right)$ and $\mathrm{T}_{6}\left(18.2 \times 10^{5}\right.$ cfu $\left.\mathrm{g}^{-1}\right)$, while minimum $\left(16.9 \times 10^{5} \mathrm{cfu} \mathrm{g}^{-1}\right)$ bacterial count with $\mathrm{T}_{8}$. Under turmeric, the data also showed a significant effect and higher bacterial count was recorded in $\mathrm{T}_{1}\left(19.8 \times 10^{5} \mathrm{cfu} \mathrm{g}^{-1}\right)$ which was statistically at par with $\mathrm{T}_{2}\left(19.6 \times 10^{5} \mathrm{cfu}\right.$ $\left.\mathrm{g}^{-1}\right), \mathrm{T}_{3}\left(19.3 \times 10^{5} \mathrm{cfu} \mathrm{g}^{-1}\right), \mathrm{T}_{4}\left(19.3 \times 10^{5} \mathrm{cfu} \mathrm{g}^{-}\right.$ $\left.{ }^{1}\right), \mathrm{T}_{5}\left(19.2 \times 10^{5} \mathrm{cfu} \mathrm{g}^{-1}\right)$ and $\mathrm{T}_{6}\left(18.9 \times 10^{5} \mathrm{cfu}\right.$ $\left.\mathrm{g}^{-1}\right)$ and lowest was under $\mathrm{T}_{8}\left(17.9 \times 10^{5} \mathrm{cfu}\right.$ $\left.\mathrm{g}^{-1}\right)$. Biswas et al., (2017) ascribed the higher bacterial count to the positive effects of manure by providing nutrients for the growth of microbes directly or indirectly by stimulating plant growth and enhancing root carbon flow. Also, the organic manures show superiority in enriching the richness and diversity of soil bacteria (He et al., 2008) due to enhanced soil microbial biomass and activities of organic treated soils (Islam et al., 2011).

\section{Fungal count}

During both the years, the fungal population was significantly affected by the application of organic nutrient sources after harvest of crop. The data pertaining to soil fungal population in potato soil revealed that the soil receiving $100 \% \mathrm{RD} \mathrm{N}$ through $\mathrm{VC} \& \mathrm{PM}$ on 50:50 N-equivalence basis $\left(\mathrm{T}_{1}\right)$ recorded maximum fungal count $\left(3.65 \times 10^{3} \mathrm{cfu}^{-1}\right)$ which was statistically at par with $\mathrm{T}_{2}$ $\left(3.45 \times 10^{3} \mathrm{cfu} \mathrm{g}^{-1}\right)$, while minimum $\left(2.40 \times 10^{3}\right.$ cfu $\mathrm{g}^{-1}$ ) was noted in $\mathrm{T}_{8}$. A similar trend was observed in turmeric i.e., highest fungal count was recorded under treatment $\mathrm{T}_{1}\left(3.58 \times 10^{3}\right.$ cfu $\mathrm{g}^{-1}$ ) which was statistically at par with $\mathrm{T}_{2}$ $\left(3.53 \times 10^{3} \mathrm{cfu} \mathrm{g}^{-1}\right)$ and $\mathrm{T}_{3}\left(3.35 \times 10^{3} \mathrm{cfu} \mathrm{g}^{-1}\right)$ and minimum in control. Ingle et al., (2014) also reported an increase in fungal population with addition of organics since most of these organisms are chemoheterotrophs, which require organic source of carbon as food and oxidation of organic substances provides energy, thereby increasing their population.

\section{Actinomycetes count}

The actinomycetes population was significantly enhanced by the application of organic nutrient sources. The data pertaining to soil actinomycetes count revealed that in potato the soil receiving $100 \% \mathrm{RD} \mathrm{N}$ through VC \& PM on 50:50 N-equivalence basis $\left(\mathrm{T}_{1}\right)$ recorded highest actinomycetes count $\left(2.71 \times 10^{3} \mathrm{cfu} \mathrm{g}^{-1}\right)$, which was statistically at par with $\mathrm{T}_{2}\left(2.61 \times 10^{3}\right.$ cfu $\left.\mathrm{g}^{-1}\right)$ and $\mathrm{T}_{3}$ $\left(2.46 \times 10^{3}\right.$ cfu $\left.\mathrm{g}^{-1}\right)$, while lowest actinomycetes was noted in $\mathrm{T}_{8}\left(2.11 \times 10^{3} \mathrm{cfu}\right.$ $\left.\mathrm{g}^{-1}\right)$. In turmeric, the pooled data also showed a significant effect and highest actinomycetes count was recorded in T1 I.E. $100 \%$ RD N $\left(2.85 \times 10^{3} \mathrm{cfu} \mathrm{g}^{-1}\right)$ which was statistically at par with $\mathrm{T}_{2}\left(2.70 \times 10^{3} \mathrm{cfu} \mathrm{g}^{-1}\right)$ and the lowest was under $\mathrm{T}_{8}\left(2.18 \times 10^{3} \mathrm{cfu} \mathrm{g}^{-1}\right)$ control.

The increased microbial population may be due to the fact that organic manure provided necessary food and micro environment for their quicker multiplication and growth (Kumari and Kumari, 2002). This could be ascribed to the organic sources which supplied large amount of readily available carbon, resulting in more diverse and dynamic microbial system. Soil enzymatic activities increased as the soil microbes degrade organic matter through the production of diverse extracellular enzymes, after the application of vermicompost to soils (Tejada and Gonzalez, 2008). This may be attributed to higher amount of growth promoting substances, vitamins and enzymes which in turn increased the microbial population and root biomass production. FYM is one of the suitable medium in which microbial 
inoculants grow to a reasonably higher number with long shelf life (Sharma, 2002).

Based on the present study it was concluded that the use of organic manures was significantly improve the soil health. Soil with application of $100 \% \quad \mathrm{RD} \mathrm{N}$ through vermicompost and poultry manure on 50:50 nitrogen equivalence basis showed highest microbial biomass carbon, dehydrogenase activity, phosphatase activity, urease activity and viable microbial count. Therefore, organic nutrient sources play a key role in sustainable agriculture by increasing the microbial activity in soil which may favourable to sustain soil productivity and maintain soil health.

\section{References}

Akca MO and Namli A. 2015. Effects of poultry litter biochar on soil enzyme activities and tomato, pepper and lettuce plants growth. Eurasian Journal of Soil Science 4: 161-168.

Bhattacharyya Ranjan, Kundu S, Ved P and Gupta H S. 2008. Sustainability under combined application of mineral and organic fertilizers in a rainfed soybeanwheat system of the Indian Himalayas. European Journal of Agronomy 28: 346.

Biswas S, Hazra GC, Purakayastha TJ, Saha $\mathrm{N}$, Mitran T, Roy SS, Basak N and Mandal B. 2017. Establishment of critical limits of indicators and indices of soil quality in rice-rice cropping systems under different soil orders. Geoderma 292: 34-48.

Biswas S, Kundu DK, Mazumdar SP, Saha AR, Majumdar B, Ghorai AK, Ghosh D, Yadav AN and Saxena AK. 2018. Study on the activity and diversity of bacteria in a New Gangetic alluvial soil (Eutrocrept) under rice-wheatjute cropping system. Journal of
Environmental Biology 39: 379-386

Casida LE Jr. 1977. Microbial metabolic activity in soil as measured by dehydrogenase determinations. Applied and environmental microbiology 34: 630-636.

He JZ, Zheng Y, Chen CR, He YQ and Zhang LM. 2008. Microbial composition and diversity of an upland red soil under long-term fertilization treatments as revealed by culture-dependent and culture-independent approaches. Journal of Soils Sediments 8: 349-358.

Ingle SS, Jadhao SD, Kharche VK, Sonune BA and Mali DV. 2014. Soil biological properties as influenced by long-term manuring and fertilization under sorghum (Sorghum bicolor)-wheat (Triticum aestivum) sequence in Vertisols. Indian Journal of Agricultural Sciences 84: 452-457.

Islam MR, Chauhan PS, Kim Y, Kim M and Sa T. 2011. Community level functional diversity and enzyme activities in paddy soils under different long-term fertilizer management practices. Biology and Fertility of Soils 47: 599-604.

Kandeler E and Gerber H. 1988. Short-term assay of soil urease activity using colorimetric determination of ammonium. Biology and Fertility of Soils 6: 68-72.

Kashyap KRS and Khokhar KK. 2017. Longterm effects of organic manures and fertilizers on soil enzymes activity. International Journal of Chemical Studies 5: 449-452.

Kumari S and Kumari K. 2002. Effect of vermicompost enriched with rock phosphate on growth and yield of cow pea (Vigna unguilata L. walp). Journal of the Indian Society of Soil Science 50: 223-224.

Lakshmi SR, Rao PC, Sreelatha T, Padmaja G, Madhavi M, Rao PV. 2014. Biochemical changes in submerged rice 
soil amended with different vermicomposts under integrated nutrient management. Journal of Indian Society of Soil Science 62: 131-139.

Liu E, Yan C, Mei X, He W, Bing HS, Ding L. 2010. Long-term effect of chemical fertilizer, straw and manure on soil chemical and biological properties in northwest China. Geoderma 158: 173180.

Mandal A, Patra AK, Singh D, Swarup A, Masto RE. 2007. Effect of long-term application of manure and fertilizer on biological and biochemical activities in soil during crop development stages. Bioresource Technology 98: 3585-3592.

Mohammadi K, Ghalavand A, Aghaalikhani M, Heidari G, Shahmoradi B, Sohrabi Y. 2011. Effect of different methods of crop rotation and fertilization on canola traits and soil microbial activity. Australian Journal of Crop Science 5: 1261-1268.

Moharana PC, Biswas DR, Patra AK, Datta SC, Singh RD, Lata.2014. Soil nutrient availability and enzyme activities under wheat-green gram crop rotation as affected by rock phosphate enriched compost and inorganic fertilizers. Journal of the Indian Society of Soil Science 62: 224-234.

Raju B, Rao PC, Reddy AP, Padmavathi P. 2013. Effect of various INM on yield, urease and dehydrogenase activity in safflower. Helix Journal 6: 405-408.

Rao S. 1999. Soil and environmental pollution - A threat to sustainable agriculture. Journal of Indian Society Soil Science 47: 611-633.

Shahid M, Nayak AK, Shukla AK, Tripathi R, Kumar A, Mohanty S, Bhattacharyya P, Raja R and Panda BB. 2013. Long-term effects of fertilizer and manure applications on soil quality and yields in a sub-humid tropical rice-rice system. Soil Use and Management 29: 322-332.

Sharma SK. 2002. Effect of Azospirillium, Azotobacter and nitrogen on growth and yield of cabbage (Brassica oleracea var. capitata). Indian Journal of Agricultural Sciences 79: 555-557.

Tabatabai MA and Bremner JM. 1969. Use of p-nitrophenyl phosphate for assay of soil phosphatase activity. Soil Biology and Biochemistry 1: 301-307.

Tejada M and Gonzalez JL. 2008. Application of Two vermicomposts on a rice crop: Effects on soil biological properties and rice quality and yield. Agronomy Journal 10: 336-34.

Vance ED, Brookes PC and Jenkinson DS. 1987. An extraction method for measuring soil microbial biomass $\mathrm{C}$. Soil Biology and Biochemistry 19: 703707.

Zhao, J., T. Ni, J. Li, Q. Lu, Z. Fang, Q. Huang, R. Zhang, R. Li, B. Shen and Q. Shen. 2016. Effects of organicinorganic compound fertilizer with reduced chemical fertilizer application on crop yields, soil biological activity and bacterial community structure in a rice-wheat cropping system. Applied Soil Ecology 99: 1-12.

\section{How to cite this article:}

Anjali Verma, Uday Sharma, D. Tripathi and Meera Devi. 2019. Effect of Organic Nutrient Sources on Biological Properties of Soil in Potato and Turmeric Cropping System. Int.J.Curr.Microbiol.App.Sci. 8(08): 1045-1052. doi: https://doi.org/10.20546/ijcmas.2019.808.121 